\title{
Evaluation of water quality of Thuthapuzha Sub-basin of Bharathapuzha, Kerala, India
}

\author{
P. Manjula ${ }^{1} \cdot$ C. Unnikrishnan Warrier ${ }^{1}$
}

Received: 4 January 2017 / Accepted: 15 March 2019 / Published online: 10 April 2019

(c) The Author(s) 2019

\begin{abstract}
Hydrochemical investigation of open well and river water samples of Thuthapuzha Sub-basin of Bharathapuzha, Kerala, was carried out to determine the spatial and temporal variations in the physico-chemical parameters. The suitability of water for drinking and irrigation purposes and the processes controlling the water chemistry were also assessed. The study area experiences a humid tropical climate and heavy rainfall of $\sim 3830 \mathrm{~mm} / \mathrm{year}$. Thirty-five open well and nine river water samples were collected during the pre-monsoon, monsoon and post-monsoon seasons. The chemical properties of the river water samples were dominated by alkaline earths and weak acids $\left(\mathrm{CaHCO}_{3}\right.$ type). Even though majority of the open well samples belonged to $\mathrm{CaHCO}_{3}$ type, few samples belonged to $\mathrm{NaCl}$, mixed $\mathrm{CaMgCl}$ and mixed $\mathrm{CaNaHCO}_{3}$ water type. The groundwater and river water chemistry of the region was influenced by the chemistry of the host rock rather than precipitation and evaporation. Except $\mathrm{pH}$ and the total iron concentration, all other physico-chemical parameters of the open well samples of the study area were within the acceptable limit of drinking purposes. The physico-chemical parameters of the entire river water samples were within the acceptable limit for drinking purpose. The entire open well and river water samples were suitable for irrigation purposes.
\end{abstract}

Keywords Hydrochemistry $\cdot$ Thuthapuzha Sub-basin $\cdot$ Kerala $\cdot$ India

\section{Introduction}

Geometric increase in population coupled with rapid urbanization, industrialization and agricultural development has resulted in high impact on quality and quantity of water in India. Hence, the availability and the quality of the freshwater resources are the most pressing of the many environmental challenges in India (CPCB 2011). The quality of water is of vital concern for mankind, since it is directly linked with human welfare. Poor quality of water adversely affects the plant growth and human health (WHO 1984; Hem 1985). A number of studies on water quality have been carried out in different parts of India (Sreedevi 2004; Semwal and Akolkar 2006; CPCB 2011; Thilagavathi et al. 2012; Brinda et al. 2014; Balwant et al. 2016). All

Deceased: C. Unnikrishnan Warrier.

P. Manjula

mp@cwrdm.org

C. Unnikrishnan Warrier

warrier@cwrdm.org

1 Centre for Water Resources Development and Management, Kunnamangalam. P. O., Kerala, India these studies reveal that both rivers and groundwater in India are facing water quality issues.

The state of Kerala, located in the south-western corner of India, is blessed with 44 rivers and heavy rainfall of $\sim 3000 \mathrm{~mm} /$ year. However, most of the water in the rivers is quickly drained into the Arabian Sea due to the steep seaward sloping of the state. Hence, in addition to rivers, the groundwater is also utilized to meet the water requirements of the state. The increase in population, development activities, urbanization, change in land-use pattern, etc. has created a concern among the people of Kerala regarding both the river water and groundwater quality of various river basins.

Several studies were attempted earlier to address the water quality of various rivers of Kerala. Nandan (2007), Jalal and Kumar (2013) and Maya et al. (2013) and Anitha et al. (2014) assessed the water quality of Periyar, Pampa, Neyyar and Chaliyar rivers, respectively. The effects of pollutants on the physico-chemical characters and nutrient load of river Kalpathipuzha, Palakkad, were studied by Divya and Manomani (2013). A comparison of water quality index (WQI) between Peruvanthanam and Valiyathodu sub-watersheds was carried out by Rekha et al. (2013). The water 


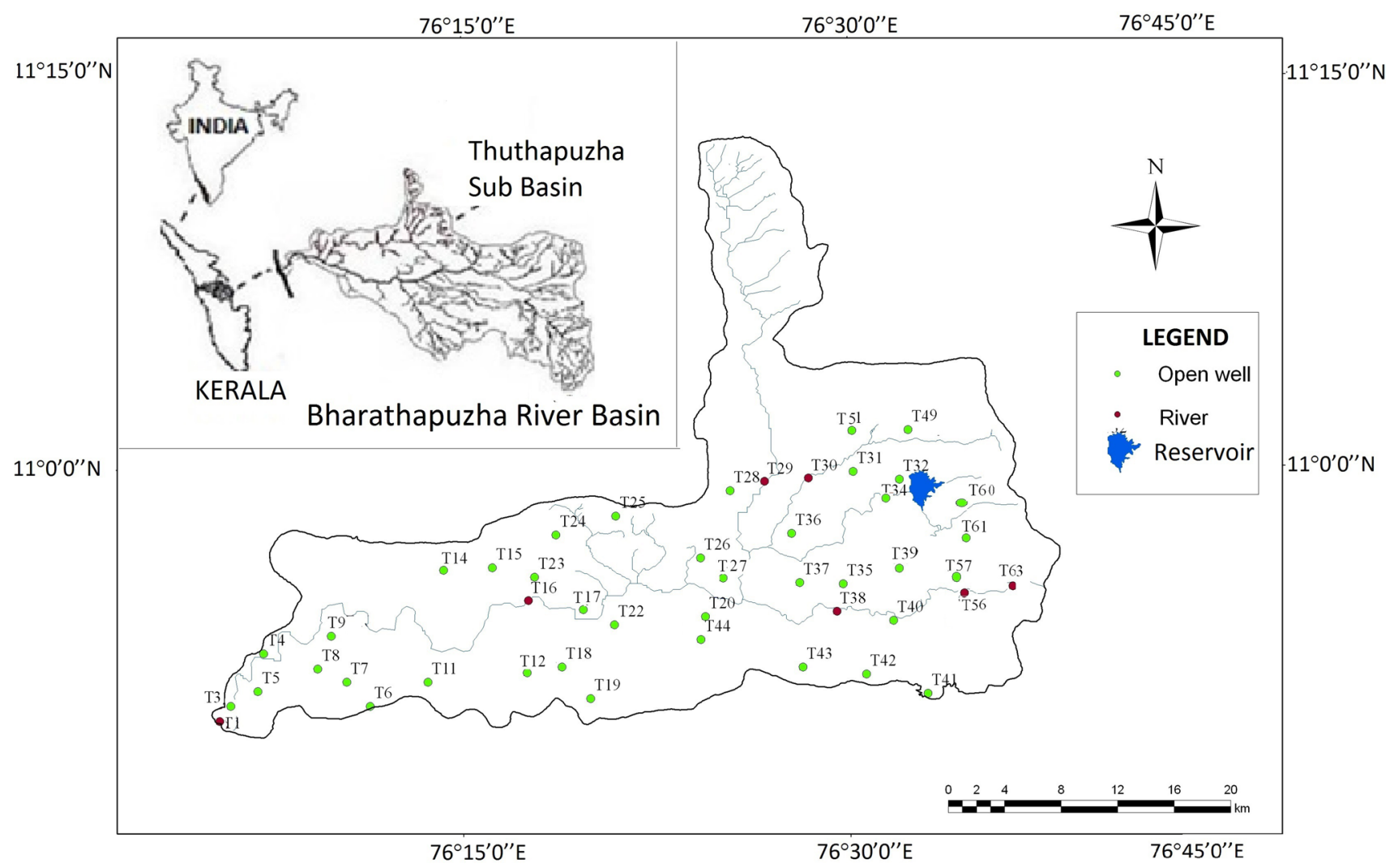

Fig. 1 Index map of the study area with sampling locations

quality of both river and groundwater of various river basins of Kerala was assessed by CWRDM (2009; 2017), groundwater of Karakulam Grama Panchayat (Jaya and Deepthi 2015), Kazhakuttam block (Binoj Kumar and Divya 2012) of Thiruvananthapuram district, coast of Ernakulam district by Sreekesh et al. (2018), etc.

Bharathapuzha River Basin, the second-longest (209 km) and the second-largest river basin of Kerala $\left(4400 \mathrm{~km}^{2}\right)$, is the lifeline of approximately four million people residing in three administrative districts, namely Malappuram, Trissur and Palakkad districts of Kerala. The river originates from different parts of the Western Ghats, as small brooks and rivulets which later join and form four major tributaries, namely Kalpathipuzha, Gayathripuzha, Thuthapuzha and Chitturpuzha (Nikhil Raj and Azeez 2010). Bharathapuzha drains with an average annual discharge of $3.94 \mathrm{~km}^{3}$ of which approximately $42 \%\left(1.6 \mathrm{~km}^{3}\right)$ is contributed by Thuthapuzha (Nikhil Raj and Azeez 2009).

Numerous studies have been carried out in Bharathapuzha River Basin on various aspects. The water availability and the status of water demands in the basin were addressed by Dinesan et al. (2004). Brijesh (2006) evaluated the groundwater conditions and developed a groundwater model for the basin. The groundwater quality issues in the shallow aquifers of Palakkad and Chittur taluks of the basin was addressed by Kannan and Sabu Joseph (2010).

The present study aims to determine the spatial and temporal variations in the physico-chemical parameters of both open well and river water samples of Thuthapuzha Sub-basin of Bharathapuzha. The suitability of water for domestic and irrigation purpose and the hydrochemical processes that control the chemistry of water in this area were also assessed.

\section{Study area}

Thuthapuzha Sub-basin $\left(10^{\circ} 50^{\prime}-11^{\circ} 15^{\prime}\right.$ north and $76^{\circ}$ $05^{\prime}-76^{\circ} 40^{\prime}$ east), located within the Palakkad and Malappuram districts of Kerala, is a sixth-order sub-basin of Bharathapuzha covering an area of $\sim 1018 \mathrm{~km}^{2}$ (Unnikrishnan Warrier and Manjula 2014). Thuthapuzha is about $63 \mathrm{~km}$ in length and has four tributaries draining to it, namely Kuntipuzha, Nellipuzha, Kanhirapuzha and Thuppanadpuzha (Fig. 1). The average annual discharge of the sub-basin is $1750 \mathrm{MCM}$ (CWC 2012). The study area falls within the midland (7.5-75 m elevation above mean sea level) and the highlands (>75 m elevation above mean sea level) region of Kerala and experiences a humid tropical climate. The Silent Valley Reserve Forest is located at the north-eastern corner of the sub-basin. The 
average annual rainfall in Thuthapuzha Sub-basin is $3830 \mathrm{~mm}$ (Manjula 2015). This is higher than the average annual rainfall (1822 mm) of entire Bharathapuzha River Basin (Nikhil Raj and Azeez 2012) and the average annual rainfall $(2817 \mathrm{~mm})$ of Kerala state (Krishnakumar et al. 2009). The rainfall is dependent on the south-west and north-east monsoons which contributes $63 \%$ and $23 \%$, respectively, of the total annual rainfall. The pre-monsoon showers also contribute $13 \%$ of the total annual rainfall. Wide spatial variation in the rainfall ranging from $2020 \mathrm{~mm}$ to more than $5000 \mathrm{~mm} /$ year is observed, and the high rainfall is towards the Silent Valley Reserve Forest (Manjula 2015). The study area is underlain by Precambrian crystalline rocks like charnockite, charnockitic gneiss, hornblende biotite gneiss, garnet biotite gneiss, khondalites, migmatites, etc. (Ravindrakumar and Chacko 1994). A gabbro dyke traverses extensive lengths of the study area (CGWB 2009). Laterite capping is observed over the major part of the study area with a maximum thickness of $20 \mathrm{~m}$ along the western part. Laterite is either absent or observed as thin capping over the country rock towards the eastern part.

\section{Methodology}

Thirty-five open well samples and nine river water samples of Thuthapuzha Sub-basin were collected using 1L depth water sampler. The samples were collected (Fig. 1) in 1-L capacity plastic containers for the physico-chemical analyses during the pre-monsoon, monsoon and post-monsoon seasons. The water samples were analysed following the standard analytical procedures and techniques reported in the literature (APHA 1995). The physico-chemical parameters like $\mathrm{pH}$ and electrical conductivity were measured in the field itself using water analyser kit (Horiba U10). Sodium and potassium present in the water samples were determined by the flame photometric method, calcium by the EDTA titrimetric method and iron by phenanthroline method. Magnesium was determined indirectly from the total hardness and the calcium hardness value. Chloride and sulphate were estimated by argentometric method and turbidity method, respectively, and the nitrate using an Ion selective electrode. Colorimetric method and stannous chloride method using a spectrophotometer were employed to determine the fluoride and phosphate in water samples. Bicarbonate present in the water samples was calculated from the measured total alkalinity values which were estimated by titration against a standard acid. All the analyses were carried out in the laboratory housed at Centre for Water Resources Development and Management, Kozhikode.

\section{Results}

The summary of the physico-chemical analyses of the water samples is presented in Table 1.
The desirable limit of $\mathrm{pH}$ of water for drinking purpose prescribed by Bureau of Indian Standards (BIS 2012) is 6.5-8.5. A low $\mathrm{pH}$ of below 6.5 can cause corrosion to metal pipes (Trivedy and Goel 1986) and gastrointestinal disorders (Rajesh et al. 2001). The $\mathrm{pH}$ of the open well samples varied from 4.60 to 7.00 during the pre-monsoon season, 4.70 to 7.00 during the monsoon season and 4.30 to 6.70 during the post-monsoon season. The $\mathrm{pH}$ of $77 \%, 66 \%$ and $71 \%$ of the open well samples during pre-monsoon, monsoon and post-monsoon seasons, respectively, was below the prescribed limit $(<6.5)$ for drinking purposes (BIS 2012). Since laterites have the capacity to generate acidity and consume majority of all dissolved oxygen in the water that infiltrates into the earth system (CESS 1984), the low pH of the open well samples of the study area may be attributed to the laterites and lateritic soil. In contrast to the open well samples which were mostly acidic, the river water samples were neutral to slightly alkaline with average $\mathrm{pH}$ value of 7.34, 7.31 and 7.30 during the pre-monsoon, monsoon and post-monsoon seasons and were within the prescribed limit for drinking purpose.

Electrical conductivity (EC) is the measure of concentration of electrolyte in water in the form of ions (Weast 1968). The electrical conductivity provides a proxy for the hydrochemistry of the study area. The electrical conductivity of the open well samples of the study area ranged from 30.00 to $350.00 \mu \mathrm{S} / \mathrm{cm}$ during the pre-monsoon season, $20.00 \mu \mathrm{S} / \mathrm{cm}$ to $430.00 \mu \mathrm{S} / \mathrm{cm}$ during the monsoon season and $20.00 \mu \mathrm{S} / \mathrm{cm}$ to $450.00 \mu \mathrm{S} / \mathrm{cm}$ during the post-monsoon season. The seasonal average of electrical conductivity during the pre-monsoon, monsoon and post-monsoon seasons was $156.74 \mu \mathrm{S} / \mathrm{cm}, 150.97 \mu \mathrm{S} / \mathrm{cm}$ and $156.51 \mu \mathrm{S} / \mathrm{cm}$, respectively. The seasonal average of electrical conductivity of the river water samples was lower than that of open well samples and was $65.11 \mu \mathrm{S} / \mathrm{cm}$ during the pre-monsoon, $49.55 \mu \mathrm{S} / \mathrm{cm}$ during the monsoon and $55.00 \mu \mathrm{S} / \mathrm{cm}$ during the post-monsoon season. The electrical conductivity of the river water increased towards the downstream direction in all the three seasons which may be due to groundwater contribution in the lower reaches of the river.

Total dissolved solids (TDS) comprise inorganic salts and small amounts of organic matter that are dissolved in water (WHO 1993). The seasonal average of TDS of open well samples during the pre-monsoon, monsoon and post-monsoon seasons was $92.89 \mathrm{mg} / \mathrm{L}, 90.57 \mathrm{mg} / \mathrm{L}$ and $93.90 \mathrm{mg} / \mathrm{L}$, respectively. The seasonal average of TDS of river water samples was $39.13 \mathrm{mg} / \mathrm{L}$ during the pre-monsoon season, $29.47 \mathrm{mg} / \mathrm{L}$ during the monsoon season and $32.93 \mathrm{mg} / \mathrm{L}$ during the post-monsoon season which were considerably lower than the open well samples. Water resources with TDS values less than $300 \mathrm{mg} / \mathrm{L}$ are considered as excellent, $300-600 \mathrm{mg} / \mathrm{L}$ are good, $600-900 \mathrm{mg} / \mathrm{L}$ are fair, $900-1200 \mathrm{mg} / \mathrm{L}$ are poor

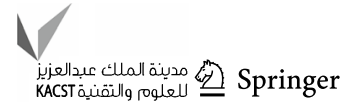


Table 1 Summary of the results of physico-chemical parameters of water samples

\begin{tabular}{|c|c|c|c|c|c|c|c|c|c|c|}
\hline \multirow[t]{2}{*}{ Parameters } & \multirow[t]{2}{*}{ Unit } & \multicolumn{3}{|c|}{ Pre-monsoon } & \multicolumn{3}{|l|}{ Monsoon } & \multicolumn{3}{|c|}{ Post-monsoon } \\
\hline & & Minimum & Maximum & Average & Minimum & Maximum & Average & Minimum & Maximum & Average \\
\hline \multicolumn{11}{|l|}{ Open well } \\
\hline $\mathrm{pH}$ & - & 4.60 & 7.00 & 5.89 & 4.70 & 7.00 & 5.95 & 4.30 & 6.70 & 5.97 \\
\hline $\mathrm{EC}$ & $\mu \mathrm{S} / \mathrm{cm}$ & 30.00 & 350.00 & 156.74 & 20.00 & 430.00 & 150.97 & 20.00 & 450.00 & 156.51 \\
\hline TDS & $\mathrm{mg} / \mathrm{L}$ & 18.00 & 210.00 & 92.89 & 12.00 & 258.00 & 90.57 & 12.00 & 270.00 & 93.90 \\
\hline $\mathrm{Na}$ & $\mathrm{mg} / \mathrm{L}$ & 2.50 & 37.50 & 13.17 & 2.80 & 35.10 & 12.26 & 3.10 & 30.90 & 13.13 \\
\hline $\mathrm{K}$ & $\mathrm{mg} / \mathrm{L}$ & 0.10 & 14.20 & 2.19 & 0.70 & 18.40 & 3.55 & 0.90 & 15.10 & 3.38 \\
\hline $\mathrm{Ca}$ & $\mathrm{mg} / \mathrm{L}$ & 1.60 & 27.25 & 14.20 & 1.80 & 27.25 & 9.13 & 1.80 & 27.25 & 10.15 \\
\hline $\mathrm{Mg}$ & $\mathrm{mg} / \mathrm{L}$ & 0.49 & 8.40 & 4.26 & 0.35 & 16.50 & 2.86 & 0.49 & 14.09 & 3.16 \\
\hline $\mathrm{Fe}$ & $\mathrm{mg} / \mathrm{L}$ & BDL & 0.52 & 0.09 & BDL & 0.90 & 0.12 & BDL & 0.46 & 0.08 \\
\hline $\mathrm{Cl}$ & $\mathrm{mg} / \mathrm{L}$ & 4.00 & 58.98 & 19.71 & 2.90 & 50.15 & 15.47 & 3.00 & 59.98 & 17.68 \\
\hline $\mathrm{HCO}_{3}$ & $\mathrm{mg} / \mathrm{L}$ & 5.06 & 60.77 & 23.51 & 6.60 & 130.00 & 34.83 & 10.00 & 106.00 & 36.79 \\
\hline $\mathrm{SO}_{4}$ & $\mathrm{mg} / \mathrm{L}$ & 0.08 & 20.00 & 2.86 & 0.09 & 10.00 & 2.05 & 0.15 & 16.00 & 2.86 \\
\hline $\mathrm{NO}_{3}$ & $\mathrm{mg} / \mathrm{L}$ & 0.18 & 24.20 & 4.43 & 0.10 & 9.80 & 1.51 & 0.12 & 10.34 & 1.49 \\
\hline F & $\mathrm{mg} / \mathrm{L}$ & BDL & 0.45 & 0.13 & BDL & 0.57 & 0.09 & BDL & 0.37 & 0.09 \\
\hline $\mathrm{PO}_{4}$ & $\mathrm{mg} / \mathrm{L}$ & BDL & BDL & BDL & BDL & BDL & BDL & BDL & 0.32 & 0.01 \\
\hline $\mathrm{SiO}_{2}$ & $\mathrm{mg} / \mathrm{L}$ & 5.95 & 41.25 & 16.75 & 1.20 & 42.00 & 12.89 & 1.50 & 45.80 & 14.69 \\
\hline \multicolumn{11}{|l|}{ River } \\
\hline $\mathrm{pH}$ & - & 7.00 & 7.80 & 7.34 & 6.80 & 7.80 & 7.31 & 6.80 & 7.60 & 7.30 \\
\hline EC & $\mu \mathrm{S} / \mathrm{cm}$ & 33.00 & 90.00 & 65.11 & 33.00 & 80.00 & 49.55 & 29.00 & 81.00 & 55.00 \\
\hline TDS & $\mathrm{mg} / \mathrm{L}$ & 20.00 & 54.00 & 39.13 & 17.40 & 48.00 & 29.47 & 17.40 & 48.00 & 32.93 \\
\hline $\mathrm{Na}$ & $\mathrm{mg} / \mathrm{L}$ & 1.90 & 8.40 & 5.31 & 1.90 & 5.10 & 3.44 & 1.90 & 6.80 & 4.17 \\
\hline $\mathrm{K}$ & $\mathrm{mg} / \mathrm{L}$ & 0.10 & 2.30 & 1.56 & 1.00 & 1.90 & 1.46 & 0.80 & 1.80 & 1.42 \\
\hline $\mathrm{Ca}$ & $\mathrm{mg} / \mathrm{L}$ & 3.21 & 12.83 & 7.88 & 3.21 & 6.41 & 4.86 & 4.81 & 7.21 & 6.23 \\
\hline $\mathrm{Mg}$ & $\mathrm{mg} / \mathrm{L}$ & 1.46 & 5.35 & 2.77 & 0.49 & 2.92 & 1.89 & 0.49 & 3.89 & 1.78 \\
\hline $\mathrm{Fe}$ & $\mathrm{mg} / \mathrm{L}$ & BDL & 0.12 & 0.06 & BDL & 0.10 & 0.07 & BDL & 0.10 & 0.07 \\
\hline $\mathrm{Cl}$ & $\mathrm{mg} / \mathrm{L}$ & 3.00 & 8.00 & 5.78 & 3.00 & 11.27 & 6.13 & 2.00 & 10.00 & 4.78 \\
\hline $\mathrm{HCO}_{3}$ & $\mathrm{mg} / \mathrm{L}$ & 10.00 & 15.19 & 13.53 & 13.04 & 34.50 & 21.10 & 13.04 & 46.00 & 26.11 \\
\hline $\mathrm{SO}_{4}$ & $\mathrm{mg} / \mathrm{L}$ & 0.35 & 8.00 & 2.42 & 0.76 & 2.50 & 1.43 & 0.89 & 1.90 & 1.15 \\
\hline $\mathrm{NO}_{3}$ & $\mathrm{mg} / \mathrm{L}$ & 0.20 & 1.80 & 0.94 & 0.18 & 0.56 & 0.32 & 0.15 & 0.60 & 0.35 \\
\hline $\mathrm{F}$ & $\mathrm{mg} / \mathrm{L}$ & BDL & 0.70 & 0.16 & BDL & 0.28 & 0.03 & BDL & 0.28 & 0.03 \\
\hline $\mathrm{PO}_{4}$ & $\mathrm{mg} / \mathrm{L}$ & BDL & BDL & BDL & BDL & BDL & BDL & BDL & BDL & BDL \\
\hline $\mathrm{SiO}_{2}$ & $\mathrm{mg} / \mathrm{L}$ & 6.66 & 17.66 & 11.92 & BDL & 6.30 & 1.07 & 0.80 & 13.20 & 8.24 \\
\hline
\end{tabular}

and greater than $1200 \mathrm{mg} / \mathrm{L}$ are unacceptable for drinking purpose (WHO 1984). The TDS of the entire open well and river water samples of the study area were less than $300 \mathrm{mg} / \mathrm{L}$ and excellent for drinking purpose.

The main source of sodium $(\mathrm{Na})$ in water is plagioclase feldspars, feldspathoids and clay minerals (Hem 1985). The seasonal average of $\mathrm{Na}$ concentration of open well samples was $13.17 \mathrm{mg} / \mathrm{L}, 12.26 \mathrm{mg} / \mathrm{L}$ and $13.13 \mathrm{mg} / \mathrm{L}$ during the pre-monsoon, monsoon and post-monsoon seasons, respectively. The seasonal average of $\mathrm{Na}$ concentration of the river water samples was $5.31 \mathrm{mg} / \mathrm{L}, 3.44 \mathrm{mg} / \mathrm{L}$ and $4.17 \mathrm{mg} / \mathrm{L}$ during the pre-monsoon, monsoon and postmonsoon seasons, respectively, which were lower than the $\mathrm{Na}$ concentration of the open well samples. The maximum permissible limit of $\mathrm{Na}$ in drinking water is $200.00 \mathrm{mg} / \mathrm{L}$
(WHO 1984). Irrespective of seasons, the entire river water and open well samples were within the highest permissible limit for drinking purpose.

Even though potassium is found extensively in rocks, its concentration in natural waters is usually low because of the resistance offered by potassium minerals to weathering and dissolution (Hem 1985). The concentration of $K$ in the open well samples ranged from 0.10 to $14.20 \mathrm{mg} / \mathrm{L}$ during the pre-monsoon season, $0.70 \mathrm{mg} / \mathrm{L}$ to $18.40 \mathrm{mg} / \mathrm{L}$ during the monsoon season and $0.90 \mathrm{mg} / \mathrm{L}$ to $15.10 \mathrm{mg} / \mathrm{L}$ during the post-monsoon season. The seasonal average of $\mathrm{K}$ concentration of the river water samples during the pre-monsoon, monsoon and post-monsoon seasons was $1.56 \mathrm{mg} / \mathrm{L}, 1.46 \mathrm{mg} / \mathrm{L}$ and $1.42 \mathrm{mg} / \mathrm{L}$, respectively. 
The calcium $(\mathrm{Ca})$ concentration of open well samples exhibited spatial and temporal variations. The seasonal average of Ca concentration of open well samples was $14.20 \mathrm{mg} / \mathrm{L}, 9.13 \mathrm{mg} / \mathrm{L}$ and $10.15 \mathrm{mg} / \mathrm{L}$ during the pre-monsoon, monsoon and post-monsoon seasons, respectively. The seasonal average of $\mathrm{Ca}$ concentration of the river water samples during the pre-monsoon, monsoon and post-monsoon seasons was $7.88 \mathrm{mg} / \mathrm{L}, 4.86 \mathrm{mg} / \mathrm{L}$ and $6.23 \mathrm{mg} / \mathrm{L}$, respectively. The calcium concentration of the entire open well and river water samples was less than $75.00 \mathrm{mg} / \mathrm{L}$ during all the three seasons and was within the highest desirable limit prescribed by BIS (2012) for drinking purposes.

The main source of magnesium $(\mathrm{Mg})$ in water is the igneous rocks containing ferromagnesian minerals like olivine, pyroxenes, amphiboles and various dark-coloured micas (Hem 1985). Magnesium content of open well samples ranged from 0.49 to $8.40 \mathrm{mg} / \mathrm{L}$ during pre-monsoon, $0.35 \mathrm{mg} / \mathrm{L}$ to $16.50 \mathrm{mg} / \mathrm{L}$ during the monsoon and $0.49 \mathrm{mg} / \mathrm{L}$ to $14.09 \mathrm{mg} / \mathrm{L}$ during the post-monsoon season. The $\mathrm{Mg}$ concentration of the river water samples showed a minimum value of $1.46 \mathrm{mg} / \mathrm{L}$ during the pre-monsoon and $0.49 \mathrm{mg} / \mathrm{L}$ during both the monsoon and post-monsoon seasons. The maximum values were $5.35 \mathrm{mg} / \mathrm{L}, 2.92 \mathrm{mg} / \mathrm{L}$ and $3.89 \mathrm{mg} / \mathrm{L}$ during the pre-monsoon, monsoon and post-monsoon seasons, respectively. The $\mathrm{Mg}$ concentration of the entire open well and river water samples was less than $30.00 \mathrm{mg} / \mathrm{L}$ in all the three seasons and was within the acceptable limit for drinking purposes prescribed by BIS (2012).

Although iron is the second most abundant metallic element in the earth's outer crust, concentrations present in water generally are small. If present in water in excessive amounts, it forms red oxyhydroxide precipitates that stain laundry and plumbing fixtures (Hem 1985). The seasonal minimum total iron concentration of both open well and river water samples was below the detectable limit (BDL) irrespective of seasons. For the open well samples, the seasonal maximum values were $0.52 \mathrm{mg} / \mathrm{L}, 0.90 \mathrm{mg} / \mathrm{L}$ and $0.46 \mathrm{mg} / \mathrm{L}$ during the pre-monsoon, monsoon and postmonsoon seasons, respectively. The seasonal maximum values of river water samples were $0.12 \mathrm{mg} / \mathrm{L}$ during the pre-monsoon and $0.10 \mathrm{mg} / \mathrm{L}$ during both the monsoon and post-monsoon seasons. Recommended upper limit for iron in drinking water was $0.3 \mathrm{mg} / \mathrm{L}$ (BIS 2012). The total iron concentration of $97 \%, 94 \%$ and $91 \%$ of the open well samples during the pre-monsoon, monsoon and post-monsoon seasons, respectively, was within the acceptable limit for drinking purpose prescribed by BIS (2012). The entire river water samples irrespective of the seasons were within the acceptable limit for drinking purpose.

Atmospheric deposition of oceanic aerosols and weathering of rock salts are the natural sources of $\mathrm{Cl}$ in water, whereas the anthropogenic sources include industrial or domestic sewage effluents and run-off from agricultural fields through fertilizers (Chattopadhyay et al. 2005). The chloride concentration of the water samples of the study area belonged to three classes, namely very oligohaline $(<5 \mathrm{mg} / \mathrm{L})$, oligohaline $(5-30 \mathrm{mg} / \mathrm{L})$ and fresh (30-150 mg/L) (Stuyfzand 1989). 3\% of open well samples during the pre-monsoon and $9 \%$ during both monsoon and post-monsoon seasons belonged to the "very oligohaline' class. $83 \%, 80 \%$ and $77 \%$ of the open well samples were 'oligohaline' and $14 \%, 11 \%$ and $14 \%$ of the open well samples belonged to the 'fresh' category during the premonsoon, monsoon and post-monsoon seasons, respectively. $33 \%, 22 \%$ and $56 \%$ of river water samples during the premonsoon, monsoon and post-monsoon seasons belonged to the 'very oligohaline', and $67 \%, 78 \%$ and $44 \%$ of the river water samples belonged to the 'oligohaline' category. $100 \%$ of the open well and river water samples during all the three seasons were within the desirable limit $(250 \mathrm{mg} / \mathrm{L})$ for drinking purpose.

The primary source of bicarbonate in natural water is the dissolved $\mathrm{CO}_{2}$ in rain water (Karanth 1989). The seasonal average of $\mathrm{HCO}_{3}$ concentration of open well samples during the pre-monsoon, monsoon and post-monsoon seasons was $23.51 \mathrm{mg} / \mathrm{L}, 34.83 \mathrm{mg} / \mathrm{L}$ and $36.79 \mathrm{mg} / \mathrm{L}$, respectively. For the rivers, the seasonal average of bicarbonate concentration was $13.53 \mathrm{mg} / \mathrm{L}$ during the pre-monsoon, $21.10 \mathrm{mg} / \mathrm{L}$ during the monsoon and $26.11 \mathrm{mg} / \mathrm{L}$ during the post-monsoon season.

In natural waters, the sulphate $\left(\mathrm{SO}_{4}\right)$ generally occurs as soluble salts of calcium, magnesium and sodium (NAS 1977). The seasonal average of $\mathrm{SO}_{4}$ concentration of the open well samples was $2.86 \mathrm{mg} / \mathrm{L}$ during both pre-monsoon and post-monsoon seasons and $2.05 \mathrm{mg} / \mathrm{L}$ during the monsoon season. For the river water samples, the seasonal average of $\mathrm{SO}_{4}$ concentration was $2.42 \mathrm{mg} / \mathrm{L}, 1.43 \mathrm{mg} / \mathrm{L}$ and $1.15 \mathrm{mg} / \mathrm{L}$ during the pre-monsoon, monsoon and post-monsoon seasons, respectively. The $\mathrm{SO}_{4}$ concentration of entire open well and river water samples irrespective of seasons was within the acceptable limit $(<200 \mathrm{mg} / \mathrm{L})$ for drinking purpose prescribed by BIS (2012).

Igneous rocks, plant and animal debris are the natural sources of nitrate to water (Chattopadhyay et al. 2005). Anthropogenic sources include seepage from septic tanks, the application of sewage and sludge to the land (Waller 1988). The seasonal average of $\mathrm{NO}_{3}$ concentration of the open well samples was $4.43 \mathrm{mg} / \mathrm{L}, 1.51 \mathrm{mg} / \mathrm{L}$ and $1.49 \mathrm{mg} / \mathrm{L}$, and for the river water samples, it was $0.94 \mathrm{mg} / \mathrm{L}, 0.32 \mathrm{mg} / \mathrm{L}$ and $0.35 \mathrm{mg} / \mathrm{L}$ during the pre-monsoon, monsoon and the post-monsoon seasons, respectively. The $\mathrm{NO}_{3}$ values of the entire open well and river water samples during all the three seasons were within the acceptable limits $(45 \mathrm{mg} / \mathrm{L})$ prescribed by the BIS (2012) for drinking purposes.

The main source of $\mathrm{F}$ in water is minerals like fluorite, apatite, amphiboles like hornblende, certain micas, cryolite 
and ralstonite (Hem 1985). $\mathrm{F}$ is among the substances for which there are both lower $(0.6 \mathrm{mg} / \mathrm{L})$ and upper $(1.2 \mathrm{mg} / \mathrm{L})$ limits of concentration in drinking water, with identified health effect and benefits for human beings (ISI 1983). Very low doses of fluoride $(<0.6 \mathrm{mg} / \mathrm{L})$ in water promote dental caries (tooth decay). However, when consumed in higher doses $(>1.50 \mathrm{mg} / \mathrm{L})$, it leads to dental fluorosis or mottled enamel (WHO 1984). The F concentration of $20 \%, 43 \%$ and $40 \%$ of the open well samples during the pre-monsoon, monsoon and post-monsoon seasons was below the detectable limit of the instrument. All the open well samples were having $\mathrm{F}$ concentration less than $0.60 \mathrm{mg} / \mathrm{L}$ irrespective of seasons. This is in contrast to the high fluoride concentration $(>1.5 \mathrm{mg} / \mathrm{L})$ in the open wells and bore wells reported by Shaji et al. (2007) from the eastern part of the Palakkad district. The country rock, hornblende biotite gneiss, was identified by them as the source of this high fluoride for both open wells and bore wells. Alkaline water depleted in calcium, low rainfall (average annual rainfall of $1200 \mathrm{~mm}$ ), longer residence time of water in the aquifer zone and intensive irrigation were the favourable factors for the dissolution of fluorine-bearing minerals in groundwater of the eastern part of Palakkad district (Shaji et al. 2007). Even though a major portion of Thuthapuzha Sub-basin is underlain by hornblende biotite gneiss, the high rainfall (average annual rainfall of $3080 \mathrm{~mm}$ ) and acidic water enriched in calcium may be the factors limiting the leaching of fluoride-bearing minerals in this region. The $\mathrm{F}$ concentration of the river water during the pre-monsoon season ranged from BDL to $0.70 \mathrm{mg} / \mathrm{L}$. Except two river water samples during the monsoon season and one sample during the post-monsoon season, the F concentration of all other river water samples was found to be BDL. The results show that the F concentration of $100 \%$ of open well samples irrespective of seasons and river water samples during both monsoon and post-monsoon seasons, respectively, was less than $0.60 \mathrm{mg} / \mathrm{L}$. The F concentration of $89 \%$ of river water samples during the premonsoon season was also less than $0.60 \mathrm{mg} / \mathrm{L}$. Very low doses of fluoride $(<0.60 \mathrm{mg} / \mathrm{L})$ in the water of the study area may promote dental caries unless $\mathrm{F}$ is supplemented from other source of food.

Phosphorous is a component of complex synthetic fertilizers widely applied in agriculture (FAO 1996). Even though the study area is dominated by agricultural activities, the $\mathrm{PO}_{4}$ concentration of the entire open well samples during the pre-monsoon and monsoon seasons was below the detectable limit. $91 \%$ of the open well samples during the post-monsoon season were also below the detectable limit. The $\mathrm{PO}_{4}$ concentration of the river water samples was below the detectable limit irrespective of seasons.

Silica dissolved in natural waters has been considered as a good indicator of weathering and water circulation conditions (Dobrzynski 2005). The $\mathrm{SiO}_{2}$ concentration of the open well samples ranged from 5.95 to $41.25 \mathrm{mg} / \mathrm{L}$ during the premonsoon, $1.20 \mathrm{mg} / \mathrm{L}$ to $42.00 \mathrm{mg} / \mathrm{L}$ during the monsoon and $1.50 \mathrm{mg} / \mathrm{L}$ to $45.80 \mathrm{mg} / \mathrm{L}$ during the post-monsoon season. The seasonal average of $\mathrm{SiO}_{2}$ concentration was $16.75 \mathrm{mg} / \mathrm{L}$, $12.89 \mathrm{mg} / \mathrm{L}$ and $14.69 \mathrm{mg} / \mathrm{L}$ during the pre-monsoon, monsoon and post-monsoon seasons. The $\mathrm{SiO}_{2}$ concentration of the river water ranged from 6.66 to $17.66 \mathrm{mg} / \mathrm{L}$ during the pre-monsoon, BDL to $6.30 \mathrm{mg} / \mathrm{L}$ during the monsoon and $0.80 \mathrm{mg} / \mathrm{L}$ to $13.20 \mathrm{mg} / \mathrm{L}$ during the post-monsoon season. The river water samples also exhibited an increase in silica content downstream of the river course. According to Gao et al. (2010), an increase in silica concentration along the river course indicates an increased input of groundwater. The increase in silica content towards the downstream of Thuthapuzha River may be due to groundwater contribution.

\section{Correlation analysis}

Correlation analyses of the physico-chemical parameters of the open well and river water samples were performed to understand the relationship between various parameters. The correlation coefficient matrix of the open well samples during the pre-monsoon monsoon and post-monsoon seasons is given in Table 2 . The positive correlation shown by the physico-chemical parameters of the open well samples is the following

1. $\mathrm{pH}$ with $\mathrm{HCO}_{3}$ during all the three seasons and with $\mathrm{Mg}$ and $\mathrm{Ca}$ during the monsoon season.

2. $\mathrm{Na}$ with $\mathrm{Cl}$ in all the three seasons and with $\mathrm{K}$ during the monsoon season.

3. $\mathrm{Mg}$ with $\mathrm{Ca}$ and $\mathrm{HCO}_{3}$ in all the three seasons.

4. $\mathrm{Ca}$ with $\mathrm{HCO}_{3}$ in all the three seasons.

5. $\mathrm{Cl}$ with $\mathrm{K}$ and $\mathrm{SO}_{4}$ during pre-monsoon season.

6. $\mathrm{K}$ with $\mathrm{Ca}, \mathrm{SO}_{4}$ and $\mathrm{HCO}_{3}$ during the pre-monsoon season and with $\mathrm{Na}, \mathrm{Cl}$ and $\mathrm{SO}_{4}$ during the monsoon season.

7. $\mathrm{SO}_{4}$ with $\mathrm{HCO}_{3}$ during the monsoon season.

The positive correlation among $\mathrm{pH}, \mathrm{Ca}, \mathrm{Mg}$ and $\mathrm{HCO}_{3}$ ions may be attributed to the weathering of common calciumbearing minerals like calcic plagioclase feldspars, pyroxenes and amphiboles present in silicate rocks of the study area.

Correlation coefficient matrix of physico-chemical parameters of the river water samples during the pre-monsoon, monsoon and post-monsoon seasons is presented in Table 3. The following ions of the river water samples showed positive correlation.

1. Na with $\mathrm{Ca}, \mathrm{Cl}$ and $\mathrm{K}$ during the pre-monsoon season; $\mathrm{Ca}$ and $\mathrm{Mg}$ during the monsoon season.

2. Na with $\mathrm{Mg}$ and $\mathrm{HCO}_{3}$ during the post-monsoon season. 
Table 2 Correlation coefficient matrix of physico-chemical parameter of the open well samples

\begin{tabular}{|c|c|c|c|c|c|c|c|c|}
\hline & $\mathrm{pH}$ & $\mathrm{Na}$ & $\mathrm{Mg}$ & $\mathrm{Ca}$ & $\mathrm{Cl}$ & $\mathrm{K}$ & $\mathrm{SO}_{4}$ & $\mathrm{HCO}_{3}$ \\
\hline \multicolumn{9}{|l|}{$T$} \\
\hline $\mathrm{pH}$ & 1 & -0.05 & 0.40 & 0.41 & -0.001 & 0.15 & 0.33 & 0.61 \\
\hline $\mathrm{Na}$ & & 1 & 0.19 & 0.29 & 0.58 & 0.33 & 0.43 & 0.004 \\
\hline $\mathrm{Mg}$ & & & 1 & 0.90 & 0.33 & 0.45 & 0.41 & 0.69 \\
\hline $\mathrm{Ca}$ & & & & 1 & 0.47 & 0.56 & 0.48 & 0.72 \\
\hline $\mathrm{Cl}$ & & & & & 1 & 0.70 & 0.55 & 0.25 \\
\hline $\mathrm{K}$ & & & & & & 1 & 0.59 & 0.53 \\
\hline $\mathrm{SO}_{4}$ & & & & & & & 1 & 0.45 \\
\hline $\mathrm{HCO}_{3}$ & & & & & & & & 1 \\
\hline \multicolumn{9}{|c|}{ Monsoon } \\
\hline $\mathrm{pH}$ & 1 & -0.003 & 0.51 & 0.56 & 0.17 & 0.23 & 0.32 & 0.56 \\
\hline $\mathrm{Na}$ & & 1 & 0.10 & 0.17 & 0.63 & 0.56 & 0.41 & 0.29 \\
\hline $\mathrm{Mg}$ & & & 1 & 0.89 & 0.14 & 0.02 & 0.15 & 0.65 \\
\hline $\mathrm{Ca}$ & & & & 1 & 0.1 & 0.04 & 0.19 & 0.53 \\
\hline $\mathrm{Cl}$ & & & & & 1 & 0.61 & 0.40 & 0.43 \\
\hline $\mathrm{K}$ & & & & & & 1 & 0.68 & 0.47 \\
\hline $\mathrm{SO}_{4}$ & & & & & & & 1 & 0.56 \\
\hline $\mathrm{HCO}_{3}$ & & & & & & & & 1 \\
\hline \multicolumn{9}{|c|}{ Post-monsoon } \\
\hline $\mathrm{pH}$ & 1 & 0.21 & 0.34 & 0.38 & 0.07 & 0.19 & 0.17 & 0.50 \\
\hline $\mathrm{Na}$ & & 1 & 0.30 & 0.41 & 0.66 & 0.35 & 0.33 & 0.27 \\
\hline $\mathrm{Mg}$ & & & 1 & 0.92 & 0.23 & 0.36 & 0.24 & 0.66 \\
\hline $\mathrm{Ca}$ & & & & 1 & 0.35 & 0.41 & 0.24 & 0.71 \\
\hline $\mathrm{Cl}$ & & & & & 1 & 0.21 & 0.08 & 0.27 \\
\hline K & & & & & & 1 & 0.28 & 0.37 \\
\hline $\mathrm{SO}_{4}$ & & & & & & & 1 & 0.22 \\
\hline $\mathrm{HCO}_{3}$ & & & & & & & & 1 \\
\hline
\end{tabular}

3. $\mathrm{Mg}$ with $\mathrm{Ca}, \mathrm{Cl}, \mathrm{K}$ and $\mathrm{SO}_{4}$ during the pre-monsoon season and with $\mathrm{HCO}_{3}$ during the monsoon season.

4. Ca with $\mathrm{Cl}, \mathrm{K}$ and $\mathrm{SO}_{4}$ during the pre-monsoon season and with $\mathrm{HCO}_{3}$ during the post-monsoon season.

5. $\mathrm{Cl}$ with $\mathrm{K}$ and $\mathrm{SO}_{4}$ during the pre-monsoon season.

\section{Hydrochemical facies}

Piper diagram (Piper 1944) was employed to express the similarity and the dissimilarity in the chemistry of water samples based on the dominant cations and anions. Based on the Piper diagram, the open well samples of the study area during the pre-monsoon season (Fig. 2) belonged to three water types. During the monsoon and post-monsoon seasons, four water types (Fig. 2) were recognized for the open well samples. Alkaline earths and weak acids $\left(\mathrm{CaMgHCO}_{3}\right.$ type) dominated in $46 \%, 45 \%$ and $54 \%$ and alkalies and strong acids ( $\mathrm{NaCl}$ type) dominated in 23\%, 27\% and 23\% of the open well samples during the pre-monsoon, monsoon and post-monsoon seasons, respectively. $31 \%$ of open well samples during the pre-monsoon, $18 \%$ during the monsoon and $3 \%$ during the post-monsoon season belonged to mixed
$\mathrm{Ca}-\mathrm{Mg}-\mathrm{Cl}$ type and $10 \%$ and $20 \%$ of samples during the monsoon and post-monsoon seasons, respectively, belonged to mixed $\mathrm{CaNaHCO}_{3}$ type.

The river water samples of the study area belonged to two water types irrespective of seasons (Fig. 2). The river water samples were dominated by alkaline earths and weak acids $(56 \%, 60 \%$ and $89 \%$ during the pre-monsoon, monsoon and post-monsoon seasons, respectively). $44 \%$ of river water samples during the pre-monsoon, $40 \%$ during the monsoon and $11 \%$ during the post-monsoon season belonged to mixed $\mathrm{CaMgCl}$ type.

\section{Mechanism controlling the chemistry of open well and river water samples}

The chemical weathering of rocks and minerals present in the basin, atmospheric precipitation and evaporation-crystallization process are the three major mechanisms controlling the major ion chemistry of both surface water and groundwater (Clarke 1924; Gibbs 1970). In the present study, Gibbs diagram (Gibbs 1970) was employed to understand and to differentiate the influences of rock-water

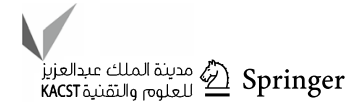


Table 3 Correlation coefficient matrix of physico-chemical parameters of the river water samples

\begin{tabular}{|c|c|c|c|c|c|c|c|c|}
\hline & $\mathrm{pH}$ & $\mathrm{Na}$ & $\mathrm{Mg}$ & $\mathrm{Ca}$ & $\mathrm{Cl}$ & $\mathrm{K}$ & $\mathrm{SO}_{4}$ & $\mathrm{HCO}_{3}$ \\
\hline \multicolumn{9}{|c|}{ Pre-monsoon } \\
\hline $\mathrm{pH}$ & 1 & 0.24 & -0.05 & 0.14 & 0.22 & 0.03 & 0.14 & -0.06 \\
\hline $\mathrm{Na}$ & & 1 & 0.43 & 0.79 & 0.89 & 0.89 & 0.32 & 0.28 \\
\hline $\mathrm{Mg}$ & & & 1 & 0.70 & 0.74 & 0.50 & 0.84 & 0.12 \\
\hline $\mathrm{Ca}$ & & & & 1 & 0.94 & 0.80 & 0.51 & 0.11 \\
\hline $\mathrm{Cl}$ & & & & & 1 & 0.83 & 0.64 & 0.20 \\
\hline K & & & & & & 1 & 0.30 & 0.39 \\
\hline $\mathrm{SO}_{4}$ & & & & & & & 1 & 0.04 \\
\hline $\mathrm{HCO}_{3}$ & & & & & & & & 1 \\
\hline \multicolumn{9}{|c|}{ Monsoon } \\
\hline $\mathrm{pH}$ & 1 & 0.31 & 0.47 & 0.41 & 0.20 & 0.36 & -0.47 & 0.37 \\
\hline $\mathrm{Na}$ & & 1 & 0.60 & 0.70 & 0.28 & 0.43 & -0.10 & 0.40 \\
\hline $\mathrm{Mg}$ & & & 1 & 0.30 & -0.11 & 0.24 & -0.20 & 0.65 \\
\hline $\mathrm{Ca}$ & & & & 1 & 0.17 & 0.01 & -0.30 & 0.41 \\
\hline $\mathrm{Cl}$ & & & & & 1 & -0.11 & -0.46 & -0.28 \\
\hline K & & & & & & 1 & 0.47 & 0.25 \\
\hline $\mathrm{SO}_{4}$ & & & & & & & 1 & -0.94 \\
\hline $\mathrm{HCO}_{3}$ & & & & & & & & 1 \\
\hline \multicolumn{9}{|c|}{ Post-monsoon } \\
\hline $\mathrm{pH}$ & 1 & 0.31 & 0.06 & 0.37 & -0.74 & 0.06 & -0.54 & 0.47 \\
\hline $\mathrm{Na}$ & & 1 & 0.66 & 0.25 & -0.02 & 0.04 & 0.33 & 0.58 \\
\hline $\mathrm{Mg}$ & & & 1 & 0.07 & 0.32 & -0.20 & 0.30 & 0.43 \\
\hline $\mathrm{Ca}$ & & & & 1 & -0.29 & 0.38 & -0.29 & 0.77 \\
\hline $\mathrm{Cl}$ & & & & & 1 & -0.17 & 0.44 & -0.34 \\
\hline K & & & & & & 1 & -0.10 & 0.45 \\
\hline $\mathrm{SO}_{4}$ & & & & & & & 1 & -0.12 \\
\hline $\mathrm{HCO}_{3}$ & & & & & & & & 1 \\
\hline
\end{tabular}

Fig. 2 Piper plot of open well and river water samples

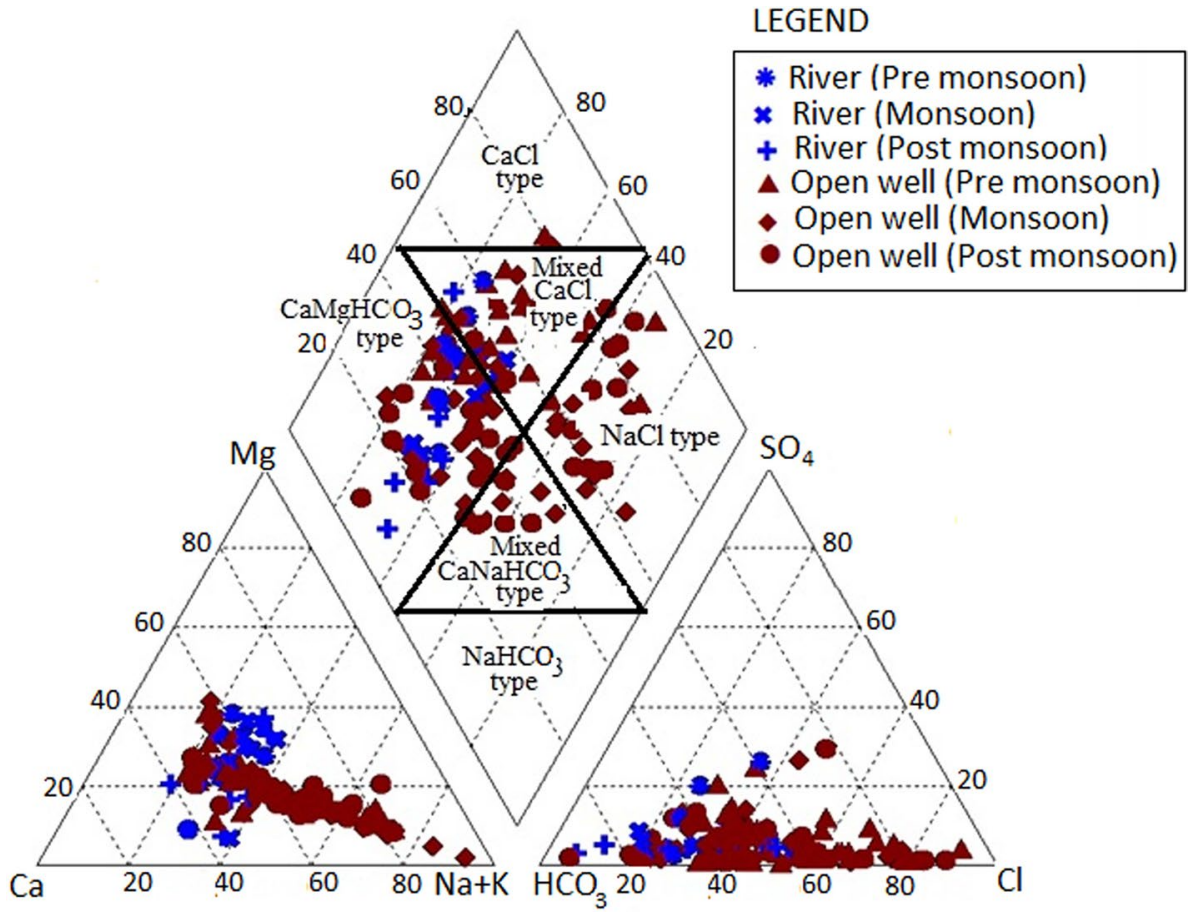


Fig. 3 a Gibbs diagram of cations of open well and river water samples, b Gibbs diagram of anions of open well and river water samples
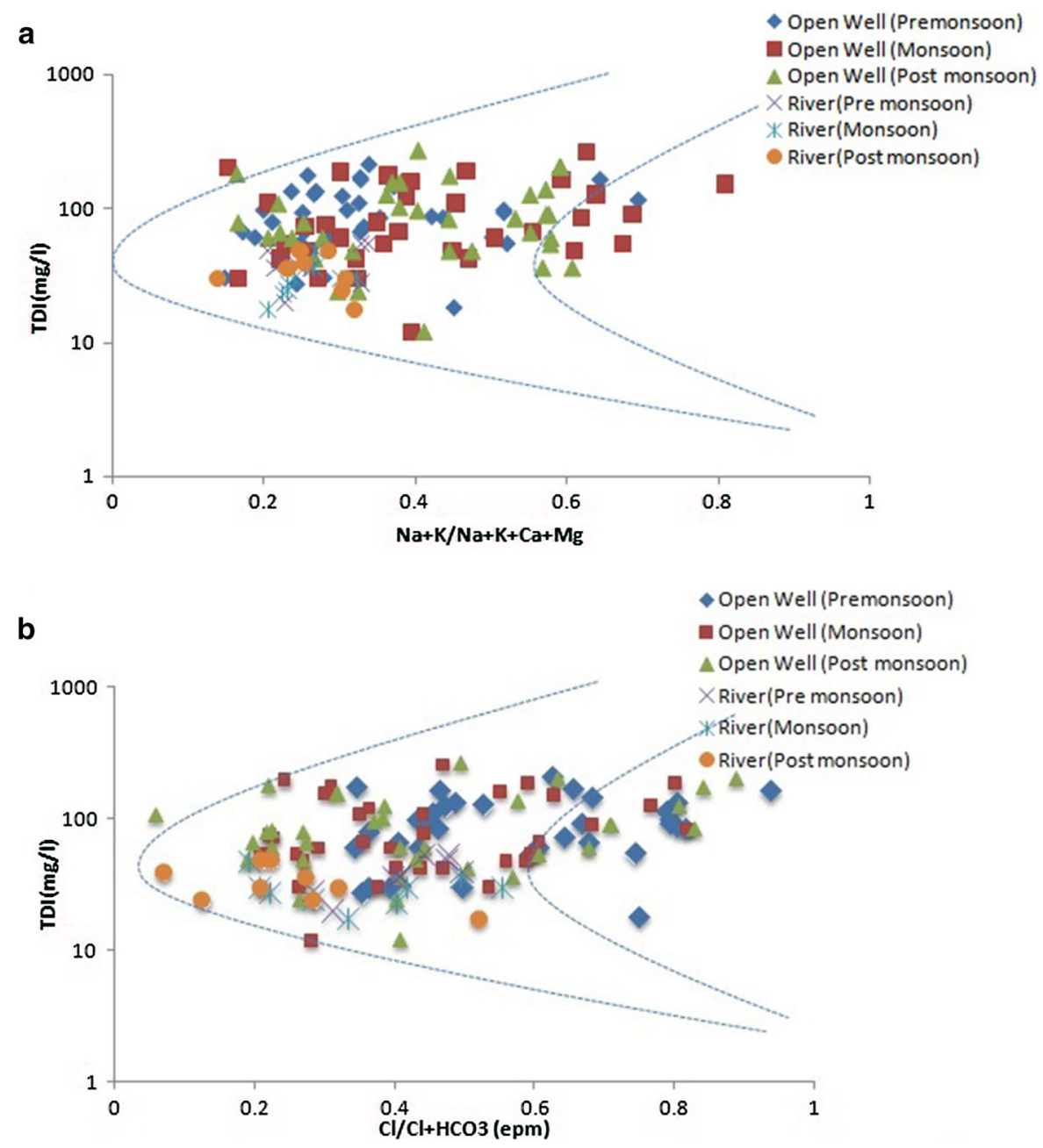

interaction, evaporation and precipitation on shallow groundwater and river water chemistry of pre-monsoon, monsoon and post-monsoon seasons. Gibbs diagram illustrates that both the open well and the river water samples fall within the water-rock interaction field irrespective of seasons (Fig. 3a, b), indicating that the weathering of rocks primarily controls the major ion chemistry of water in this region.

\section{Irrigation water quality}

The quality of water plays an important role in irrigated agriculture. The suitability of water for irrigation is contingent upon the effects of mineral constituents of water on both plant and the soil (Hill 1942; Anon 1946). The most important characteristics which determine the suitability of water for irrigation are salinity, sodium percentage, sodium adsorption ratio (SAR), residual sodium carbonate (RSC) and permeability index.
Salinity is broadly related to total dissolved solids (TDS) and electrical conductivity (EC). High concentrations of TDS and electrical conductivity in irrigation water may increase the soil salinity. The salts in the water affect the growth of plants directly and also affect the soil structure, permeability and aeration, which indirectly affect plant growth (Todd 1959). Water with electrical conductivity less than $250 \mu \mathrm{S} / \mathrm{cm}$ is considered as excellent, between 250 and $750 \mu \mathrm{S} / \mathrm{cm}$ as good, $750-2250 \mu \mathrm{S} / \mathrm{cm}$ as medium, $2250-4000 \mu \mathrm{S} / \mathrm{cm}$ as bad and greater than $4000 \mu \mathrm{S} / \mathrm{cm}$ as very bad for irrigation.

The electrical conductivity of $86 \%$ of the open well samples during both pre-monsoon and post-monsoon seasons and $84 \%$ of the open well samples during the monsoon season was 'excellent'. $14 \%$ of open well samples during both pre-monsoon and post-monsoon seasons and $16 \%$ of open well samples during the monsoon season were 'good' for irrigation. 
Fig. 4 USSL diagram of open well samples

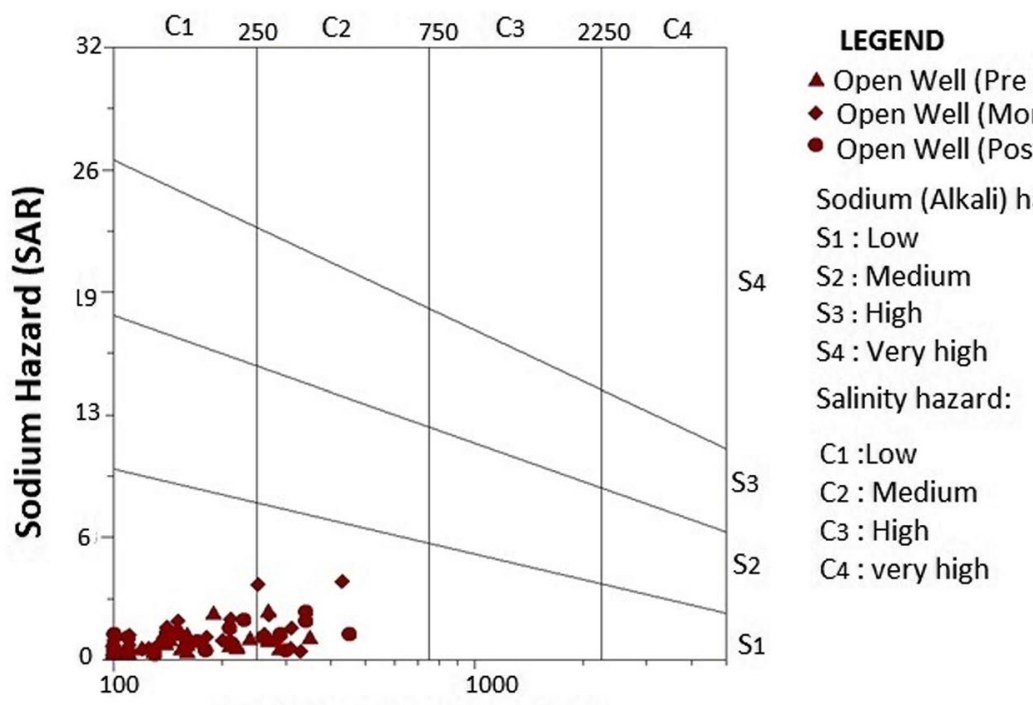

Salinity Hazard (Cond)
Sodium concentration is important in classifying irrigation water because sodium reacts with the soil to reduce its permeability. Sodium content of water is expressed in terms of sodium percentage ( $\mathrm{Na} \%$ ) (Wilcox 1955).

$\mathrm{Na} \%=\frac{(\mathrm{Na}+\mathrm{K})}{\mathrm{Ca}+\mathrm{Mg}+\mathrm{Na}+\mathrm{K}} * 100$

where all ionic concentrations are expressed in milliequivalents per litre (epm).

Based on the Na\%, Wilcox (1955) classified the irrigation waters into excellent (<20 Na\%), 'good' (20-40 Na\%), 'permissible' (40-60 Na\%), 'doubtful' (60-80 Na\%) and 'unsuitable' $(\mathrm{Na} \%>$ than $80 \%)$.

The Na\% of open well samples ranged from 13 to $67 \%$ during the pre-monsoon, $18 \%$ to $79 \%$ during the monsoon and $20 \%$ to $74 \%$ during the post-monsoon season. For the river water samples, the $\mathrm{Na} \%$ varied from 23 to $39 \%, 28$ to $39 \%$ and 20 to $38 \%$ during the pre-monsoon, monsoon and post-monsoon seasons, respectively. Nine per cent of open well samples during the pre-monsoon season and 3\% during the monsoon season were excellent for irrigation. 57\%, $37 \%$ and $34 \%$ were good during the pre-monsoon, monsoon and post-monsoon seasons, respectively. $34 \%$ of open well samples during all the three seasons were permissible, and $26 \%$ and $32 \%$ of open well samples during the monsoon and post-monsoon seasons were doubtful for irrigation. The entire river water samples during the pre-monsoon, monsoon season were good for irrigation.

The degree to which irrigation water tends to enter into cation exchange reactions in soil is indicated by the sodium adsorption ratio (SAR). This index quantifies the proportion of sodium to calcium and magnesium ions in a sample. US Salinity Laboratory of the Department of Agriculture recommends SAR as an important parameter in classifying irrigation waters (Richards 1954)

$\mathrm{SAR}=\frac{\frac{\mathrm{Na}}{\sqrt{\mathrm{Ca}}+\sqrt{\mathrm{Mg}}}}{2}$,

where the concentrations are expressed in meq/L.

According to this classification, the water samples with SAR values less than 10 are considered as excellent, $10-18$ as good, 18-26 as doubtful and $>26$ as unsuitable for irrigation. The SAR values of the entire open well and river water samples of the study area were found to be less than 10 irrespective of seasons. Hence, based on the SAR values, all the open well samples and river water samples were 'excellent' for irrigation. The classification of water for irrigation was also represented graphically by plotting the values of specific conductance and SAR on the USSL diagram. The sixteen classes in the diagram indicated the extent that the water can affect the soil in terms of salinity hazard and sodium hazard. Open well samples of the study area when plotted on the USSL diagram fell in the $\mathrm{C} 1 \mathrm{~S} 1$ and $\mathrm{C} 2 \mathrm{~S} 1$ field, indicating low salinity hazard and low to medium sodium hazard for the pre-monsoon, monsoon and post-monsoon seasons (Fig. 4).

Residual sodium carbonate (RSC) is the excess sum of $\mathrm{HCO}_{3}{ }^{-}+\mathrm{CO}_{3}{ }^{-}$in water over the sum of $\mathrm{Ca}^{2+}+\mathrm{Mg}^{2+}$ (Eaton 1950) and is calculated using the equation

$\mathrm{RSC}=\left(\mathrm{HCO}_{3}^{-}+\mathrm{CO}_{3}^{-}\right)-\left(\mathrm{Ca}^{2+}+\mathrm{Mg}^{2+}\right)$.

Concentration is expressed in meq/L.

Water containing excess of carbonate and bicarbonate tends to precipitate calcium and magnesium present in the soil as their carbonates. As a consequence, the relative proportion of sodium increases and gets fixed in the 
soil, thereby decreasing the soil permeability. A negative RSC indicates that sodium build-up is unlikely since sufficient calcium and magnesium are in excess of what can be precipitated as carbonates. Positive RSC indicates that sodium build-up in the soil is possible. If the RSC exceeds $2.5 \mathrm{meq} / \mathrm{L}$, the water is unsuitable for irrigation, if RSC is between 1.25 and $2.5 \mathrm{meq} / \mathrm{L}$, then the water is of marginal quality, and if RSC is $<1.25$, then the water is suitable for irrigation (Lloyd and Heathcote 1985). The RSC values of $100 \%$ of the open well and river water samples during the pre-monsoon, monsoon and post-monsoon seasons, respectively, were less than $1.25 \mathrm{meq} / \mathrm{L}$, and hence, these waters were suitable for irrigation.

The soil permeability is affected by the long-term use of irrigation water as it is influenced by $\mathrm{Na}^{+}, \mathrm{Ca}^{2+}, \mathrm{Mg}^{2+}$ and $\mathrm{HCO}_{3}{ }^{-}$content of the soil. Doneen (1964) evolved a criterion for assessing the suitability of groundwater for irrigation based on the permeability index (PI), where concentrations are in $\mathrm{meq} / \mathrm{L}$.

$\mathrm{PI}=\left(\mathrm{Na}+\sqrt{ } \mathrm{HCO}_{3}\right) /\left(\mathrm{Ca}^{2+}+\mathrm{Mg}^{2+}+\mathrm{Na}^{2+}\right) * 100$.

Accordingly, the PI is classified as class I ( $>75 \%)$, class II $(25-75 \%)$ and class III $(<25 \%)$. Class I waters are categorized as excellent, and class II waters are categorized as good for irrigation. Class III waters are unsuitable with $25 \%$ of maximum permeability. The PI values of $51 \%, 91 \%$ and $74 \%$ of the open well samples were excellent, and $49 \%, 9 \%$ and $26 \%$ of the open well samples during the pre-monsoon and post-monsoon seasons, respectively, were good for irrigation. $22 \%$ and $89 \%$ of river water samples were excellent, and $78 \%$ and $11 \%$ of river water samples were good during the pre-monsoon and post-monsoon seasons, respectively. The entire river water samples during the monsoon season were excellent for irrigation.

Generally, $\mathrm{Ca}^{+}$and $\mathrm{Mg}^{+}$maintain a state of equilibrium in groundwater. More $\mathrm{Mg}^{+}$present in waters affects the soil quality converting it to alkaline and decreases crop yield. Szabolcs and Darab (1964) proposed magnesium hazard (MH) value for irrigation water as given by the following formula

$\mathrm{MH}=\mathrm{Mg} /\left(\mathrm{Ca}^{2+}+\mathrm{Mg}^{2+}\right) * 100$,

where the concentrations are expressed in meq/L.

$\mathrm{MH}$ values $>50$ are considered harmful and unsuitable for irrigation purposes. Magnesium hazard values of the open well samples ranged from 16 to $46 \mathrm{meq} / \mathrm{L}, 24$ to $49 \mathrm{meq} / \mathrm{L}$ and 22 to $45 \mathrm{meq} / \mathrm{L}$ during the pre-monsoon, monsoon and post-monsoon seasons, respectively. For the river water samples, the magnesium hazard values varied from 27 to $47 \mathrm{meq} / \mathrm{L}$ during the pre-monsoon and $11 \mathrm{meq} / \mathrm{L}$ to $49 \mathrm{meq} / \mathrm{L}$ during both the monsoon and post-monsoon seasons. Based on the magnesium hazard values, the entire open well and river water samples were suitable for irrigation.

\section{Conclusions}

Physico-chemical parameters of open well and river water samples of Thuthapuzha Sub-basin of Bharathapuzha were determined to evaluate the suitability of water for drinking and irrigation purposes. The chemical properties of the river water samples were dominated by alkaline earths and weak acids $\left(\mathrm{CaHCO}_{3}\right.$ type). Even though majority of the open well samples belonged to $\mathrm{CaHCO}_{3}$ type, few samples belonged to $\mathrm{NaCl}$, mixed $\mathrm{CaMgCl}$ and mixed $\mathrm{CaNaHCO}_{3}$ water type. The groundwater and river water chemistry of the region was influenced by the chemistry of the host rock rather than precipitation and evaporation.

$80 \%, 66 \%$ and $83 \%$ of the open well samples during premonsoon, monsoon and post-monsoon seasons, respectively, were acidic with $\mathrm{pH}$ value below the prescribed limit for drinking purposes. The low $\mathrm{pH}$ of the open well samples can be due to the laterites and the lateritic soil since laterites have the capacity to generate acidity and consume majority of all dissolved oxygen in the water that infiltrates into the earth system. The total iron concentration of $3 \%, 6 \%$ and $9 \%$ of the open well samples during the pre-monsoon, monsoon and post-monsoon seasons, respectively, was below the acceptable limit for drinking purpose. Except $\mathrm{pH}$ and the total iron concentration, all other physico-chemical parameters of the open well samples of the study area were within the acceptable limit of drinking purposes. The physicochemical parameters of the entire river water samples were within the acceptable limit for drinking purpose. The entire open well and river water samples were suitable for irrigation purposes.

Acknowledgements The study forms part of the fist author's doctoral programme at Kannur University. The work also forms part of the Centre for Water Resources Development and Management Plan-funded project 'Hydrochemical and Isotopic Characterization of Thuthapuzha Sub Basin of Bharathapuzha'. Dr. Resmi, T.R., is acknowledged for all the help and support provided for this study. Ms. Surya, Ms. Abhisha and Ms. Haritha are acknowledged for analytical support. The authors are thankful to the Executive Director, Centre for Water Resources Development and Management, Kozhikode, for permission to publish the manuscript.

Open Access This article is distributed under the terms of the Creative Commons Attribution 4.0 International License (http://creativeco mmons.org/licenses/by/4.0/), which permits unrestricted use, distribution, and reproduction in any medium, provided you give appropriate credit to the original author(s) and the source, provide a link to the Creative Commons license, and indicate if changes were made. 


\section{References}

Anitha AB, Shahul Hammed A, Prasad NB (2014) Integrated river basin master plan for Chaliyar Proc. In: International symposium on integrated water resources management (IWRM-2014) CWRDM, Kozhikode, Kerala, pp 167-176

Anon (1946) The salt problem in irrigation agriculture. United States department of agriculture miscellaneous publication, vol 607, Washington, $\mathrm{p} 27$

APHA (1995) Standard methods for the examination of water and waste water, 19th edn. American Public Health Association, Washington

Balwant K, Umesh KS, Indrani M, Basu MD (2016) Water quality status of Indian major rivers with reference to agriculture and drinking purposes. In: Raman VAV (ed) Geoanthropogenic environment an appraisal. A.K.Publications, Delhi, pp 65-81

Binoj Kumar RB, Divya MP (2012) Spatial evaluation of groundwater quality in Kazhakuttam block, Thiruvananthapuram District, Kerala. J Geol Soc India 80:48-56

BIS (2012) Specifications for drinking water, IS: 10500, 2012. Bureau of Indian Standards, New Delhi, p 18

Brijesh VK (2006) Hydrogeological studies and Groundwater modelling in Bharathapuzha Basin, Kerala, India, In: Unpublished Ph.D. Thesis submitted to University of Mysore, Mysore, p 94

Brindha K, Neena Vaman KV, Srinivasan K, Sathis Babu M, Elango L (2014) Identification of surface water- groundwater interaction by hydrogeochemical indicators and assessing its suitability for drinking and irrigational purposes in Chennai, Southern India. Appl Water Sci 4:159-174

CESS (1984) Resource atlas of Kerala. Centre for Earth Science Studies, Thiruvanthapuram

CGWB (2009) Ground water information booklet of Malappuram district, Kerala. p 28

Chattopadhyay S, Asa Rani L, Sangeetha PV (2005) Water quality variations as linked to landuse pattern: a case study in Chalakudy river Basin, Kerala. Curr Sci 89(12):2163-2169

Clarke FW (1924) Data of geochemistry, 5th edn. U.S. Gov. Print. Off, Washington, $\mathrm{p} 770$

CPCB (2011) Status of water quality in India, MINARS/35/2013-14, p 211

CWC (2012) Integrated hydrological data book (Non classified river basins), Central Water Commission, p 675

CWRDM (2009) Environmental monitoring programme on water quality, Report submitted to KSCSTE, p 174

CWRDM (2017) Water quality status of Thiruvananthapuram district Kerala. In: Report submitted to centre for development studies, Thiruvananthapuram, $\mathrm{p} 32$

Dinesan VP, Anitha AB, Gopakumar R (2004) Water resources scenario of Bharathapuzha River Basin. In: Proceedings of industrial environmental conference, pp 36-48

Divya KR, Manomani K (2013) Assessment of water quality of river Kalpathypuzha, Palakkad, District Kerala. IOSR J Environ Sci Toxicol Food Technol 4(4):59-62

Dobrzynski D (2005) Silica origin and solubility in groundwater from the weathered zone of sedimentary rocks of the intra-sudetic Basin, SW Poland. Acta Geol Pol 55:445-462

Doneen LD (1964) Notes on water quality in agriculture, Published as science and engineering paper. Department of Water Science and Engineering, University of California, $\mathrm{p} 48$

Eaton EM (1950) Significance of carbonate in irrigation water. Soil Sci 69:123-133

FAO (1996) Control of water pollution from agriculture. In: Edvin DO (ed) Food and agriculture organisation of the United States Drainage paper No. 55. p 101
Gao X, Wang Y, Wu P, Guo Q (2010) Trace elements and environmental isotopes as tracers of surface water groundwater interaction: a case study at Xin' an karst water system, Shanxi Province, Northern China. Environ Earth Sci 59:1223-1234

Gibbs RJ (1970) Mechanisms controlling world water chemistry. Science 170:1088-1109

Hem JD (1985) Study and interpretation of the chemical characteristics of natural water. U.S. Geological survey water-supply Paper, 2254: $\mathrm{p} 263$

Hill RA (1942) Salts in irrigation water. T Am Soc Civ Eng 107:1478-1518

ISI (1983) Indian standard specification for drinking water. IS: 10500, Indian Standard Institute, New Delhi

Jalal FN, Sanal Kumar MG (2013) Water quality assessment of Pamba river of Kerala, India in relation to pilgrimage season. Int J Res Chem Environ 3(1):341-347

Jaya DS, Deepthi GP (2015) Assessment of groundwater quality in Karakulam Grama Panchayath in Thiruvananthapuram, Kerala State, South India. Int J Geol Environ Eng 9(10):1209-1213

Kannan N, Joseph Sabu (2010) Quality of groundwater in the shallow aquifers of a paddy dominated agricultural river basin, Kerala, India. Int J Civ Environ Eng 2(3):160-178

Karanth KR (1989) Hydrogeology, New Delhi, India. Tata Mc Graw, Hill Publishing Company Limited, New York, p 458

Krishnakumar KN, Rao GSLHVP, Gopakumar CS (2009) Rainfall trends in twentieth century over Kerala, India. Atmos Environ 43:1940-1944

Lloyd JW, Heathcote JA (1985) Natural inorganic hydrochemistry in relation to ground water: an introduction. Clarendon Press, Oxford, p 296p

Manjula P (2015) Hydrological and Hydrochemical characterization of Thuthapuzha Sub Basin of Bharathapuzha. Thesis submitted to Kannur University, Kannur

Maya K, Remya SI, Baburaj B, Baijulal B, Lekshmi I, Nisha UR, Sangeetha J, Padmalal D (2013) Natural and anthropogenic determinants of water quality changes in a small tropical river basin, SW India. Int J Agric Sci 3(1):363-372

Nandan SB (2007) A perspective on the ecology and bioresources of the Rivers of Kerala. In: Proceedings of DAE-BRNS National symposium on limnology (NSL-07), pp 8-14

NAS (1977) Drinking water and health. Washington, DC, National Research Council, National Academy of Sciences, Washington

Nikhil Raj PP, Azeez PA (2009) Spatial and temporal variation in surface water chemistry of a tropical river, the river Bharathapuzha, India. Curr Sci 96(2):245-251

Nikhil Raj PP, Azeez PA (2012) Trend analysis of rainfall in Bharathapuzha river basin, Kerala, India. Int J Climatol 32:533-539

Piper AM (1944) A graphical procedure in the chemical interpretation of Groundwater analysis. Trans Am Geophys Union 25:914-923

Raj N, Azeez (2010) Land use and land cover changes in a tropical river basin: a case from Bharathapuzha River Basin, Southern India. J Geogr Inf Syst 2:185-193

Rajesh R, Sreedhara Murthy TR, Raghavan BR (2001) Spatial distribution of $\mathrm{pH}, \mathrm{EC}$ and total dissolved solids of Nethravathi river basin, Karnataka state, India. Pollut Res 20(3):413-418

Ravindrakumar GR, Chacko T (1994) Geothermobarometry of mafic granulites and metapelite from the Palghat Gap, South India: petrological evidence for isothermal uplift and rapid cooling. J Metamorph Geol 1:479-492

Rekha VB, George AV, Rita M (2013) A comparative study of water quality index (WQI) of Peruvanthanam and Valiyathodu subwatersheds of Manimala river basin, Kerala, South India. IOSR J Environ Sci Toxicol Food Technol 3(4):1-6

Richards LA (1954) Diagnosis and improvement of saline and alkali soils. Agricultural Handbook vol 60, Washington, DC, USA, p 160 
Semwal N, Akolkar P (2006) Water quality assessment of sacred Himalayan rivers of Uttaranchel. Curr Sci 91(4):486-496

Shaji E, Bindu Viju J, Thambi DS (2007) High fluoride in groundwater of Palghat District, Kerala. Curr Sci 92(2):240-245

Sreedevi (2004) Groundwater Quality of Pageru River Basin, Cuddapah District, Andhra Pradesh. J Geol Soc India 64(5):619-636

Sreekesh S, Sreerama Naik SR, Rani Seema (2018) Effect of sea level changes on the groundwater quality along the coast of Ernakulam District, Kerala. J Clim Change 4(2):51-62

Stuyfzand PT (1989) A new hydrochemical classification of water types with examples of application. AHS 184:89-98

Szabolcs I, Darab C (1964). The influence of irrigation water of high sodium carbonate content of soils. In: Proceedings of 8th international congress of ISSS, Transmission, vol 2, pp 803-812

Thilagavathi R, Chidambaram S, Prasanna MV, Thivya C, Singaraja C (2012) A study on groundwater geochemistry and water quality in layered aquifers system of Pondicherry region, southeast India. Appl Water Sci 2:253-269

Todd DK (1959) Groundwater hydrology, I edn. Willey, Hoboken, p 336

Trivedi RK, Goel PK (1986) Chemical and biological methods for water pollution studies. Environmental publication, India, p 215
Unnikrishnan Warrier C, Manjula P (2014) River: groundwater interaction of a tropical Sub Basin of Bharathapuzha, Kerala, India. Int J Adv Technol Eng Sci 2(7):382-393

Waller RM (1988) Ground water and the rural homeowner. USGS, p 36

Weast RC (1968) Handbook of chemistry and physics (49th ed.): Cleveland, Ohio, Chemical Rubber Co., p. Al-F286

WHO (1984) Guide lines for drinking water quality, v.1 Recommendations, World Health Organization Geneva

WHO (1993).Guidelines for drinking water quality, Geneva, Switzerland. 2nd edn, vol 1, p 150

Wilcox LV (1955) Classification and use of irrigation waters, U.S. Department of Agriculture Circular 969, Washington, DC: U.S. Department of Agriculture, 19-20

Publisher's Note Springer Nature remains neutral with regard to jurisdictional claims in published maps and institutional affiliations. 